Journal of

Innate Immunity
Editorial

J Innate Immun 2021;13:61-62

DOI: $10.1159 / 000515202$
Received: February 8, 2021

Accepted: February 9, 2021

Published online: March 19, 2021

\title{
Modelers Modelling Models
}

What would science be without models? Cell models have been established to mimic the in vivo situation, systems biology to mimic cellular processes, and animal models to mimic diseases in human beings. Within the last decades, these experimental models had an enormous impact on a better understanding of the molecular mechanisms behind many diseases. Also, in this issue of Journal of Innate Immunity, several models are described. For instance, Gomez-Lopez et al. [1] employed an intra-amniotic infection model to demonstrate that the transcriptomic changes in amniotic fluid monocytes/ macrophages are associated with the severity of the fetal inflammatory response. These findings led the authors to conclude that in amniotic fluids innate immune cells play an important role in cellular trafficking throughout the umbilical cord [1]. Their observations are in line with results showing that many immune cells have organ-specific and distinct functional populations and innate immune functions [2-5].

Also, Nie et al. [6] in their contribution used a disease model, namely LPSinduced acute lung injury (ALI), to show that polyADP-ribosylation of NFATc3 and NF- $\kappa$ B transcription factors can modulate macrophage inflammatory gene expression. Based on their findings, the authors draw the conclusion that PARP-1 inhibitors can be employed to therapeutically prevent LPSinduced ALI. Notably, several other pulmonary models have also demonstrated an important function of macrophages in pathogen recognition and elimination that is dependent on their priming $[3,7,8]$. An important role for NK cells in evoking an anti-tumor immune response is reported by Lee et al. [9]. Due to their cellular model the authors were able to show that resveratrol represents a promising anti-cancer drug candidate by boosting the activity of NK cells. In the last study in this issue, Dekmak et al. [10] are using an insect model to investigate whether and to what extent the contribution of systemic immune defenses to host microbial resistance varies if bacteria invade the hemolymph after crossing the midgut epithelium subsequent to an oral infection.

As always, we hope that the selection of articles will attract the attention of the readership of the Journal of Innate Immunity and emphasize the importance of experimental models.

(C) 2021 The Author(s)

Published by S. Karger AG, Basel

This is an Open Access article licensed under the Creative Commons Attribution-NonCommercial-4.0 International License (CC BY-NC) (http://www.karger.com/Services/OpenAccessLicense), applicable to the online version of the article only. Usage and distribution for commercial purposes requires written permission. 


\section{References}

1 Gomez-Lopez N, Romero R, Varrey A, Leng $\mathrm{Y}$, Miller D, Done B, et al. RNA sequencing reveals diverse functions of amniotic fluid neutrophils and monocytes/macrophages in intra-amniotic infection. J Innate Immun. 2020 Nov: $1-20$

2 Stockfelt M, Christenson K, Andersson A, Björkman L, Padra M, Brundin B, et al. Increased $\mathrm{CD} 11 \mathrm{~b}$ and decreased $\mathrm{CD} 62 \mathrm{~L}$ in blood and airway neutrophils from long-term smokers with and without COPD. J Innate Immun. 2020;12(6):480-9.

3 Michaeloudes C, Bhavsar PK, Mumby S, Xu B, Hui CK, Chung KF, et al. Role of metabolic reprogramming in pulmonary innate immunity and its impact on lung diseases. J Innate Immun. 2020;12(1):31-46.
4 van Riet S, van Schadewijk A, de Vos S, Vandeghinste N, Rottier RJ, Stolk J, et al. Modulation of airway epithelial innate immunity and wound repair by $\mathrm{M}(\mathrm{GM}-\mathrm{CSF})$ and $\mathrm{M}(\mathrm{M}$ CSF) macrophages. J Innate Immun. 2020; 12(5):410-21.

5 Zulu MZ, Martinez FO, Gordon S, Gray CM. The elusive role of placental macrophages: the hofbauer cell. J Innate Immun. 2019;11(6): $447-56$.

6 Nie Y, Nirujogi TS, Ranjan R, Reader BF, Chung S, Ballinger MN, et al. PolyADP-ribosylation of NFATc3 and NF-kappaB transcription factors modulate macrophage inflammatory gene expression in LPS-induced acute lung injury. J Innate Immun. 2020 Oct 12:1-11.
7 Tanner L, Single AB. Animal models reflecting chronic obstructive pulmonary disease and related respiratory disorders: translating pre-clinical data into clinical relevance. J Innate Immun. 2020;12(3):203-25.

8 Rao L, Eissa NT. Autophagy in pulmonary innate immunity. J Innate Immun. 2020;12(1): 21-30.

9 Lee Y, Shin H, Kim J. In vivo anti-cancer effects of resveratrol mediated by NK cell activation. J Innate Immun. 2020 Sep:1-13.

10 Dekmak AS, Yang X, Zu Dohna H, Buchon N, Osta MA. The route of infection influences the contribution of key immunity genes to antibacterial defense in anopheles gambiae. J Innate Immun. 2020 Nov:1-20. 